\title{
Collaboration between Teachers and Librarians for Information Literacy Curriculum: A Case Study of a Hong Kong Secondary School
}

\author{
Jean Lai, Ph.D. (Corresponding author) \\ Department of Computer Science, Hong Kong Baptist University \\ Kowloon Tong, Kowloon, Hong Kong \\ Tel: 852-3411-5597, Fax: 852-3411-7892 \\ E-mail: jeanlai@comp.hkbu.edu.hk
}

Danmei Wei, MSc.

Faculty of Education, The University of Hong Kong

Pokfulam, Hong Kong

Tel: 86-18920799863, Fax: Nil

E-mail: mei.iris34@gmail.com

Received: June 14, 2012

doi:10.5296/jse.v3i3.3859
Accepted: July 20, 2013 Published: August 1, 2013

URL: http://dx.doi.org/10.5296/jse.v3i3.3859

\begin{abstract}
Information literacy is a set of skills needed to find, retrieve, analyze, and use information. Based upon a case study conducted for this paper, in a secondary school in Hong Kong, the aim of this research is to verify and evaluate the status of current development of integration of information literacy into the curriculum and examine the collaboration between the teachers and librarians at the school in this process. The status of existing collaboration in this school is discussed based upon the interviews. The results clearly illustrate that the librarians as well as the teachers' understanding of the existing information literacy instruction framework is not satisfactory. Through the curriculum, the integration of information literacy into the curriculum could be utilized to enhance the students' skills in information literacy, while cooperation between the librarians and teachers also has the potential to be greatly
\end{abstract}


enhanced and strengthened. Furthermore, a conclusion and suggestions are provided to contribute towards enhanced collaboration in the curriculum, which would have the ability to empower students to be information literate learners.

Keywords: Information literacy, Curriculum, Collaborations between teachers and librarians 


\section{Introduction}

Information literacy is usually defined as a set of skills needed to "recognize when information is needed and have the ability to locate, evaluate, and use effectively the needed information” (American Library Association, 1989). In an information society, information literacy is increasingly important to equip people for every aspect of life. Such a process of inquiry thus demands that students should possess a wide range of skills which can be developed through independent, collaborative, life-wide and life-long learning. A primary goal of education is to empower students to possess such life-long skills that can be used beyond their classroom.

Within the kindergarten through twelfth grade (K-12) (i.e. Form 7 grade in Hong Kong) environment, effective curriculum development is vital to the development of information literacy skills in students. Eisenberg (2008) strongly recommends adopting a collaborative approach to curriculum development among classroom teachers, librarians, technology teachers, and other educators. Staff must be encouraged to work together to analyze student curriculum needs, develop a broad instruction plan, set information literacy goals, and design specific unit and lesson plans that integrate information skills and classroom content. These educators can also collaborate on teaching and assessment duties. In some schools, the school librarians' partner could be a single teacher, or a group of teachers from one or several disciplines, depending on the situation.

In this study, some remarkable studies and achievements are highlighted including information literacy standards in education (Kuhlthau, 1993; Eisenberg \& Berkowitz, 1990; American Association of School Librarians \& Association for Educational Communications and Technology, 1998; Association of College and Research Libraries, 2000); integration of information literacy in the curriculum (Fister, 2008); and the collaboration between librarians and teachers (Jacobs, 1997; Jenlin, 2003). Most importantly, the report on Information Literacy Framework for Hong Kong Students released by the Education and Manpower Bureau in Hong Kong in 2005 has been reviewed in this paper. For the purpose of instruction, information literacy can be delivered through various methods (Cox \& Lindsay, 2008). A review and case study of an information literacy class is discussed in Johnston \& Webber (2003). The American Library Association (ALA) also provides some guiding principles for collaboration in the curriculum. An overview of essential ingredients for collaboration is included.

Based upon different perspectives, studies and theories conducted, it is understood that information literacy instruction commands increasing attention in the field of education. In addition, a number of these debates lay emphasis upon secondary school-based education. This study aims to concentrate on exploring the roles of the librarians and teachers and their collaborations in secondary schools. In Taiwan, Jenlin (2003) developed his study to examine the relationship between information literacy and integration of Information Technology into the curriculum of junior secondary school teachers. In Hong Kong, it has been increasingly noticed that information literacy instruction is receiving greater attention in schools. With this information in mind, the Education and Manpower Bureau working group (Education and Manpower Bureau, 2005) carried out a study to develop an Information Literacy Framework 
for Hong Kong students and give suggestions about the implementation of policies and strategies. But the report lacks an in-depth study and exploration of the practice of information literacy instruction. How would librarians and the teachers, as the instructors of information literacy, enable students to master information literacy skills and how would they perform in the process of collaboration, especially in inculcating information literacy instruction into the curriculum? Policy-making decisions, especially with regard to the evolution of education in Hong Kong, are gradual and slow, which raises the question as to how librarians and the teachers could ensure the introduction of information literacy instruction in the curriculum. These questions have not been thoroughly investigated until now. This study aims to understand the current status of information literacy instruction methods and the collaboration between librarians and teachers in the curriculum in secondary schools in Hong Kong.

This study plans to explore the current status of information literacy instruction in secondary schools in Hong Kong, with a view to critiquing how librarians and teachers communicate and collaborate in the curriculum. A case study approach is used to describe and explore the process and relationships in this topic (Denscombe, 2007). A secondary school in Hong Kong was selected for this case study. Interviews were conducted for the purpose of data collection in order to explore the complexity of the subject and gain insights from the perspectives of both teachers and librarians. Librarians as well as subject teachers in the school were invited for interviews.

\section{Literature Review}

This section begins with a condensed introduction of the definition of information literacy and subsequently, proceeds to an overview of variant descriptions about information literacy standards for student learning. This is followed by an explanation of information literacy instruction models, the anticipated learning outcomes and finally, the methods adopted in Secondary Schools for instruction in Hong Kong are presented. Furthermore, the collaboration between librarians and the teachers during the instruction process is discussed.

\section{Information Literacy}

The concept of "information literacy" was introduced for the very first time in 1974, by Paul Zurkowski, the president of the US Information Industry Association (IIA), in his proposal of a national program submitted to the National Commission on Libraries and Information Science (NCLIS) (Manchester Metropolitan University, 2007). In over three decades since that time, the definition of information literacy has evolved and has been further developed by different authors in their articles. When Burchinal (1976) presented his idea of "information literacy" in his article, "The Communications Revolution: America's Third Century Challenge," he mentioned that an information literate person should obtain a set of skills, knowledge, and behavior around information use to support their learning in the digital age. After three years, The Information Industry Association (IIA) expanded the notion that information literacy requires not only the skills but also related techniques, for retrieving, analyzing and ultimately, utilizing information. In the 1980s, this concept of information literacy entered the field of education. In 1989, The American Library Association (ALA) 
Presidential Committee on Information literacy was established to focus on the development of information literacy. In the Final Report, it states, "to be information literate, a person must be able to recognize when information is needed and have the ability to locate, evaluate, and use effectively the needed information" (American Library Association, 1989). This definition, thus far has been considered as the most widely accepted one for all people to refer to Spitzer, Eisenberg, Lowe, \& Doyle (1998).

\section{Information Literacy Standards}

According to Zurkowski, an additional explanation in his definition of information literacy is that, "People trained in the application of information resources to their work can be called information literates. They have learned techniques and skills for utilizing the wide range of information tools as well as primary sources in moulding information solutions to their problems" (Behrens, 1994). With further advances in the definition and its application in the 70 s, the definition of information literacy was further enriched to mean "the requirements of skills to locate and use information" (Burchinal, 1976), as well as "the techniques and skills for using information tools in molding solutions to problems” (Garfield, 1979).

Subsequently, when the notion of information literacy broadened and was used in the field of education, it was linked with the concept of computer literacy (Horton, 1983), and was defined as "the bundle of information skills that may be required to function in society" (Compaine, 1984). Since that time, two sets of definitions and standards, which identified the actual meaning of the specific set of information skills, were developed respectively for kindergarten through twelfth grade (K-12) (i.e. Form 7 grade in Hong Kong) education and higher education. Kuhlthau (1987 \& 1993) used an information search process model to explain information literacy as a way of learning. The Big Six information skills model (Big6) (Eisenberg \& Berkowitz, 1990) is considered as one of the most popular models in the area of K-12 education. The American Association of School Librarians (AASL) \& Association for Educational Communications and Technology (AECT) (1998) further contributed to higher education by developing The Nine Information Literacy Standards for Student Learning and sufficient supporting materials are provided to illustrate the application of these standards. The Association of College and Research Libraries (ACRL) (2000) also set up the Information Literacy Competency Standards for Higher Education, and Eisenberg (2008) brought forth an updated version comparing relevant models of information literacy in his article.

With the ever-escalating complexity of the 21st century information society in which they live, individuals are increasingly faced with diverse, abundant information that comes to them in different and unfiltered formats. In school settings, it is becoming more and more important for students to possess a diverse set of information literacy skills. In 2005, the Information Literacy Working Group in Hong Kong completed a study on the development of an Information Literacy Framework for Hong Kong students and the Education and Manpower Bureau released this report. Based on a coding scheme and the analysis of eight frameworks, the study established that the information literacy standards derived from the frameworks can be classified accordingly into four key dimensions of learning: cognitive, 
meta-cognitive, affective and socio-cultural dimensions. In the cognitive dimension, an information literate person is able to locate the information needed and apply them in problem-solving and decision making process. Based on the information, an information literate person is also able to construct new concepts or understanding. In the meta-cognitive dimension, an information literate person knows that information processing is an iterative process. He is able to plan, monitor and regulate the process. In the affective dimension, an information literate person can work independently and enjoys learning. In the socio-cultural dimension, an information literate person is able to contribute positively to the society. The Information Literacy Framework contained these four dimensions, and eleven standards and thirty-two indicators were formulated to embody it.

\section{Information Literacy Instruction}

School-based instruction methods can be modified depending on the situation and environment prevalent in different countries and in different schools. The book "Information Literacy Instruction Handbook," edited by Christopher N. Cox and Elizabeth Blakeseley Lindsay (Cox \& Lindsay, 2008), reports that information literacy is often delivered in two ways: teaching several sessions which are integrated into the subject curriculum, or teaching information literacy as a stand-alone concept. Thomas W. Eland described a program which teaches information literacy as a separate course (Cox \& Lindsay, 2008, Chapter 5). On the other hand, Eisenberg (2008) mentioned that "curriculum information overload” has been one of the recurrent problems faced by educationists globally. Therefore, he suggests implementing information skills into the curriculum, and a collaborative approach is advocated. The goal to integrate information literacy into course materials is to make the instruction relevant to students by contextualizing instruction within the research projects or certain specific assignments. Fister (2008) also stated the benefits of instruction through the curriculum in her essay. In addition, she summed up some of the most common frameworks of instruction and approaches in course-related integration. For instance, in some cases, librarians meet multiple times with a particular class for the task of designing, teaching, and even evaluating students' work.

In Hong Kong, there are three proposed implementation models: Information Technology (IT) / library lesson coordinating; curriculum infusion; and Project Based Learning (PBL) coordinating (Education and Manpower Bureau, 2005). The first model utilizes IT or library lessons, which already are a part of the curriculum, as a coordinating subject. The curriculum infusion method seeks to integrate the information literacy framework into all curriculums in basic education. Finally, the PBL coordinating option attempts to use project-based learning across the curriculum in order to train and prepare students to be information literate. It is the option of the school to choose the method that it considers most appropriate and suitable for its students' development.

\section{The Expertise of the Librarians and Teachers}

As the Information Age has slowly but surely become a conscious part of people's thinking, the volume of information has increased considerably and it has become imperative for students to become discerning consumers. It is also noticed that students interact more and 
more with people and resources in the environment. In schools, the role of teachers has changed from knowledge providers to instructors of knowledge exploration (Siemens, 2002). It is also deemed necessary for librarians to be able to "take a lead role in developing and delivering learning support strategies to ensure the true meaning of information literacy" (Anday, 2006). In this research, the collaboration between teachers and librarians for English as a subject is taken as representative. The Curriculum Development Council of Hong Kong published a Guide, which announced the syllabi for the English language curriculum for secondary schools in 1999. This Guide enumerates the details of the aims of the English Language Curriculum; the subject organization; and teaching strategies and plans for teachers. Besides, library resources are also mentioned as a vital support structure in the curriculum. Furthermore, the Guide lays emphasis on the fact that to coach students to learn to be critical information users is the responsibility of an alliance of school teachers and librarians.

In actual practice, how does collaboration between teachers and librarians work? Collaboration involves ongoing communication between teachers and the school librarians about shared goals for student learning. The ideal partnership can be interpreted as: Each understands the other's role, views one another as partners and respects the expertise in the process of collaboration. They plan the goals together to achieve them, as well as share leadership, resources and responsibility in student learning. A successful collaborative practice requires both teachers and school librarians to know each other's strengths. Table 1 illustrates the various abilities in addition to the expertise required by teachers as well as librarians for teaching.

Table 1 . The Strengths required by School Librarians and Teachers

\begin{tabular}{|l|l|}
\hline School Librarian & Teacher \\
\hline Skills for accessing new knowledge & Knowledge of the curricular content \\
\hline $\begin{array}{l}\text { An understanding of the inquiry process } \\
\text { and knowledge of the research process }\end{array}$ & Knowledge of the learning process \\
\hline $\begin{array}{l}\text { Knowledge of print and electronic } \\
\text { resources }\end{array}$ & Knowledge of students \\
\hline $\begin{array}{l}\text { Knowledge of techniques for using } \\
\text { technology to enhance learning }\end{array}$ & Knowledge of teaching strategies \\
\hline $\begin{array}{l}\text { A repertoire of successful practices with a } \\
\text { variety of teachers, students, and } \\
\text { technologies }\end{array}$ & A repertoire of practices with a wide \\
\hline
\end{tabular}

\section{The Collaboration between Librarians and Teachers}

Within the K-12 environment, effective curriculum development is vital to imparting information literacy skills to students. Fister (2008) discusses the potential benefits of 
integrating information literacy into courses and the curriculum in schools. Moreover, Thomas W. Eland has explained a case in which librarians play the role of a "coach" (Cox \& Lindsay, 2008, Chapter 5). This is because, it is the role of faculty members to be involved in teaching information literacy and hence they are keen to draw on the expertise of librarians to improve students' aptitudes and skills to find and use information across the curriculum.

Given the already heavy load on students, efforts must be made to avoid a potential curriculum overload in education. Eisenberg (2008) strongly recommends adopting a collaborative approach to curriculum development among classroom teachers, librarians, technology teachers, and other educators. Staff must be encouraged to work together to analyze students' curriculum needs, develop a broad instruction plan, set information literacy goals, and design specific unit and lesson plans that integrate information skills and classroom content. These educators can also collaborate on teaching and assessment duties. Collaboration brings teachers and school librarians together to assess the needs, while designing and implementing teaching and learning activities, as well as mapping the curriculum, and in the process, teach students to gain a heightened capacity of information literacy. In some schools, the school librarians' partner could be a single teacher, or a group of teachers from one or several disciplines.

When teachers and librarians work together to consider collaborative planning, one of the major tasks they encounter is related to curriculum mapping. According to Jacobs (1997), curriculum maps that result from the mapping process involve all the elements of the curriculum: content, standards, topics being taught in the classroom throughout the year, skills and so on. Curriculum maps are necessary for teachers to collaborate with librarians to integrate information literacy skills into the school curriculum. Teachers can adopt three steps whilst designing a curriculum map (Jacobs, 1997).

Table 2. Steps to Design Curriculum Map

\begin{tabular}{|l|l|}
\hline Step 1 & $\begin{array}{l}\text { Collect professional materials and internal and external data and } \\
\text { read extensively on curriculum mapping. }\end{array}$ \\
\hline Step 2 & $\begin{array}{l}\text { Decide on the kind of information to be gathered, by perusing } \\
\text { carefully a number of sample curriculum maps, which will aid in } \\
\text { determining the categories to be included in their particular maps. }\end{array}$ \\
\hline Step 3 & $\begin{array}{l}\text { Collect data based on the curriculum of the school. Various formats } \\
\text { are available for data collection, and it is up to each individual } \\
\text { school to devise the format best suited to its faculty. }\end{array}$ \\
\hline
\end{tabular}

In the process of mapping, it is important for teachers to work together with school librarians. With a thorough knowledge of the subject area and grade level, librarians can collaborate with teachers to design the appropriate learning activities, and provide resources that support and improve the curriculum. In the process, students' information literacy capacities can be 
greatly enhanced across the curriculum (Apple Corp., 2001, p.65-73).

Throughout the curriculum as well as the classes, the library supplies the information and materials needed by teachers and students to foster language learning. In addition, immense emphasis is laid upon mastering skills pertaining to information literacy. In order that students may improve their skills by using various interactive information formats and activities provided by the library, the teacher should design the learning process, by taking maximum advantage of the range of pedagogical facilities the library offers, whilst accessing different learning materials and acquiring the appropriate teaching tools (Curriculum Development Council, 1999).

Based on a qualitative study of the teacher and librarian collaboration, five essential issues could especially facilitate the success of collaboration: school culture, positive attributes of collaborators, communication, management, and motivation (Montiel-Overall, 2008).

Obviously, the importance of collaboration between librarians and the teachers is an accepted fact. Research has been conducted on the study of the information literacy instruction framework for Hong Kong secondary students, and teaching literature acknowledges the role of the librarian in the modern school setting. In spite of world-wide research supporting the collaboration between teachers and librarians; in Hong Kong, there still persists a gap in research on partnership between librarians and teachers for the purpose of information literacy instruction. On the foundation of the literature review, this research tries to explore how librarians and teachers understand the notion of information literacy, their consciousness of their own individual expertise in its implementation, the current status of information literacy instruction methods and the collaboration in the curriculum in secondary schools under the current education policies in Hong Kong.

\section{Research Design}

This research investigates the current situation and collaboration between teachers and librarians in the integration of information literacy within the curriculum for students of a secondary school in Hong Kong. In this study, qualitative method is applied as the main research approach because it has an edge on developing an initial understanding of the issue under discussion and subsequently, deriving more in-depth information on the cases that will be discussed in subsequent sections.

\section{Sample Selection}

Teachers and librarians who are currently employed by the school are invited to participate in this study, which includes teachers who teach in both the primary and senior grades, in order to be able to generalize the result. Four of the participants (three subject teachers and one library director) are interviewed individually. All of the interviews are conducted at the library in the School. Table 3 elucidates the profiles of the participants in the survey 
Table 3. Profiles of Participants in Interview

\begin{tabular}{|l|l|l|}
\hline Participants & Position & Teaching Grade \\
\hline T1 & Subject teacher & Form 1 \& Form 2 \\
\hline T2 & Subject teacher & Form 1 \& Form 5 \\
\hline T3 & Subject teacher & Form 1 \& English unit \\
\hline L1 & Librarian Director & All forms \\
\hline
\end{tabular}

\section{Data Collection}

In this research, a set of open-ended questions are used to conduct the interview. The questions are classified into four categories:

1. The understanding and identification of information literacy: This category aims to outline the definition of information literacy for secondary school students from the perspectives of both the librarians and teachers.

2. The roles and responsibilities of librarians and teachers in the school: This category is utilized to ascertain the librarians and teachers' understanding of their positions in providing information literacy instruction.

3. The collaboration between librarians and teachers throughout the curriculum: This category aids our understanding of the specific interaction and cooperation in the subject.

4. The evaluation process: Ultimately, the study attempts to understand the factors that affect the collaboration as well as the results in information literacy instruction.

\section{Result and Data Analysis}

\subsection{The understanding and identification of information literacy}

The interview with the Librarian Director (L1) reveals that the implementation of information literacy at the School is via three major methods: information technology class, library class and integration in subject curriculum.

The Librarian Director (L1) identifies information literacy capacity as consisting of information searching skills, problem-solving ability, the use of search tools and library collections. On the other hand, the teachers do not define information literacy as an independent concept out of their instruction. The response given by both the second and third interviewees was, "We do not really think about this concept in the course of preparing for our class or even as we actually teach in the class."

For both the Librarian Director (L1) and teachers (T1, T2 and T3), there are no specific guidelines on the standards or requirements for the teaching of information literacy. Similarly, their assessment of students' information literacy abilities appears vague. During the interview, the Librarian Director (L1) opined, "Usually, we try to figure out what the 
students' needs are and arrange the lessons for them on the basis of our experience." It is inferred that the Librarian Director (L1)'s views are based on experience. Meanwhile, the teachers for the most part follow subject instructions such as textbooks or teacher references and requirements are gradually increased depending on the class grade.

\subsection{The responsibilities of librarians and teachers in the school (division of work)}

Librarians: The chief responsibility of librarians is to help primary as well as secondary school students. In performing this task, their main aim is to aid and assist in the co-ordination of the transition of primary school students to secondary school. The Librarian Director (L1) observed that, "Every year when new students come to the school, we organize lessons to help familiarize them with the school library." The set of skills imparted by librarians at the school include how to use library resources accurately to gain maximum advantage from these resources; search skills such as the Big 6 skills:[ 1) Task Definition; 2) Information Seeking Strategies; 3) Location and Access; 4) Use of Information; 5) Synthesis - Putting it all together; 6) Evaluation;] the use of search engines; the use of school databases; how to accurately locate the correct books and lastly, how to identify and analyze information. In addition, librarians have a role to support teachers in all subjects and improve the students' search skills and reading skills.

Teachers: Information literacy skills and requirements are infused in the curriculum in basic education, thus reinforcing the responsibility of the subject teachers to ensure and guarantee that students obtain the subject knowledge. The teachers therefore, meet the requirements of curriculum aims, even as they prepare students for semester examinations by educating them in the curriculum content. The responsibilities of teachers are mainly to help students master language forms and communication functions and to develop and improve the students' proficiency in the four language skills of listening, speaking, reading and writing.

The teachers stated that for the English curriculum, the principal aims are to upgrade the students' capabilities and aptitudes to: understand essential messages; abstract keywords; ascertain the target audience; summarize the essence of a passage or book; take notes; correctly answer questions related to their readings; deduce and derive the main substance of their reading by finding definite key points; and finally, be able to speak individually in front of an audience or even participate in group discussions.

The learning objectives are different for primary and senior secondary students. Teacher (T2) cited an example, "For primary students, the topic is always made more interesting and the questions are relatively easy, such as, 'Name a famous person in Hong Kong'..." "Primary students are required to understand and verify the salient features in their reading materials; while senior students should have the ability and skills to decipher and discern the argument made in a speech.”

Teacher (T3) remarked during the interview that, “As Hong Kong continues to develop and make its education policy progressive, the Education Bureau is looking at fine-tuning the Medium of Instruction (MOI), with the intention of implementing English at the Secondary 1 level starting from the 2010/11 school year, and it will then continue to implement English as 
the MOI each year, up to a higher form at junior secondary levels.” This in turn would imply that English will be the main medium of instruction in other subjects such as Physics, Chemistry, and Geography. It was also pointed out that an additional responsibility for English teachers is to help students gain proficiency in English reading and writing skills, in order for students to progress not only in English but also in other subjects, when they advance to higher grades.

\subsection{Collaboration between Librarians and Teachers}

The School has a policy of holding meetings between librarians and teachers of every subject and grade at the beginning of each year and each school term, with the aim of discussing the arrangement of activities (related to their respective subjects) and their intended collaboration throughout that academic year. These subjects include Chinese, English, Science, Mathematics, Geography, Religion etc. The primary activity on which they concentrate is the reading program; with each program lasting for two or thee weeks and this is held once a month. Before commencing the reading program, the librarians and teachers discuss topics appropriate to each grade-level and book lists. The Librarian Director (L1) declared that, "It is not always easy to communicate with and get all the librarians and teachers to work harmoniously with so many subjects in the curriculum.” During the library period, it is the responsibility of the subject teacher to take the students to the library and encourage them to utilize library resources and reading materials.

In order to teach English to the students, teachers are encouraged to plan the curriculum based upon their teaching experience, with the assistance of relevant and applicable teaching materials. English teachers are also advised to discuss their teaching methods with other colleagues teaching English in the same grade.

Each term, students have several English books to read to improve their command and grasp of the language. This book list is primarily selected by the teacher in charge of the English department and the list is provided by the library. All communication for imparting English language training occurs between the librarians and this teacher responsible for the English department. The teachers assist the students by teaching reading skills and answer students' questions in class. After the assigned reading task is completed, students are required to write a report which will be marked by the English teacher for that class. It is the responsibility of the librarian to record the students' scores for future retrieval, when it is time for the teachers to evaluate the students, and the student with the best scores is rewarded. It was noted that throughout the teaching process, the teachers did not extensively discuss and analyze students' needs and requirements with the librarian.

It is the duty of the teacher to organize and arrange an information literacy teaching unit in class, in order to train students to locate, seek, understand, select and use information that they require. For Primary students, the teachers work through integrating various teaching units throughout the term. The students have reading lists for self reading and they have reading lessons every Tuesday. During this lesson, the teacher educates the students on how to suitably read their books or perform several proficiency exercises to practice and thereby, improve their skills. Above and beyond this, students are also assigned a research topic for 
study once a term. For the Form 1 grade, the teacher allocates a topic to the students and checks the veracity of the information the next time they have a class. Teacher (T1) was of the view that, "If I did not check their work, the students would very likely 'search for' something from Yahoo and just put the material together, completely ignoring the accuracy or inaccuracy of that information.” For grades Form 4 to 6, instruction and practice in the class is more exam-oriented focusing on the Hong Kong Diploma of Secondary Education (DSE) examination which is a public examination for all secondary school students in Hong Kong. The examination result would affect their enrollment in University. Furthermore, Teacher (T1) mentioned that students are set exercises on websites, which are accessed via library computers, and this helps in honing their computer literacy skills.

The Library also organizes other activities such as book recommendations during the lunch break, where teachers assist the students to select appropriate books through subtle suggestions and proposals on suitable reading. The teacher attempts to further train students by recommending cross-disciplinary books for their reading activity.

In order to fine-tune the Medium of Instruction (MOI) policy, the school holds a workshop, which is comprised of ten lessons in one term. This workshop in turn is divided into five classes (reading, writing, and an integrated class) to meet the requirements of Form 1 and 2 students, and students are assessed for a suitable class, based on grades they secure in the workshop.

It was perceived that there was minimal communication and interaction between the teachers and library, especially in the matter of librarians rendering support to teachers for their teaching resources. The teachers in turn, hardly ever sought suggestions and help from the librarians, and preferred to seek out books or videos in the library on their own. Teacher (T3) in fact emphatically stated that she would prefer to buy a book she needed from an online book-store, as the school library would not necessarily have an updated version of all books.

\subsection{The Evaluation}

After collaboration on the reading program, the teachers and librarians conducted an evaluation of the preparation and content of the program. This typically involved reflecting on the enthusiasm and motivation displayed by students to participate in the reading program, in addition to updating the materials related to the reading program activities. The staff at the school intends to start a data-base system to evaluate and record information and facts on the reading program collected through the academic year, based upon communication and cooperation between the librarians and teachers. The school also plans to organize a workshop for students, aimed at collecting feedback from students, about their efforts to develop and enhance their knowledge skills and learning outcomes.

It was perceived that at the school the librarians demonstrated no interest to get involved in evaluation and assessment of the curriculum, and it was primarily the responsibility of subject teachers to assess, evaluate and comment on students' performances during teachers' meetings.

\section{Results Interpretation}




\subsection{The implementation model:}

Overall, the implementation model of the information literacy framework at the school would be understood as "library / IT courses and activities plus integration into the subject curriculum." In order to achieve the objectives of the information literacy framework development, librarians and teachers would need to work in collaboration and cooperate to realize the objectives.

5.2 The comparison of information literacy standard and learning outcomes in English as a subject

The Curriculum Guide prepared by the Hong Kong Curriculum Development Council (CDC) for English language (Form 1-5) (1999), lays down guidelines on all matters relating to curriculum development for the school system. The Guide logically explains that the foundation laid during the primary school years will greatly aid towards a smooth transition for students from primary to secondary school, whilst fundamentally focusing on the application of the English language to every day learning situations. Therefore, it is significantly advantageous to combine training in information literacy skills and capacities with the teaching process of the curriculum content. In accordance with the anticipant learning outcomes of information literacy skills for Levels 3 and 4 (The Information Literacy Framework assumes that all Secondary students (Form 1 to 3 ) should possess Level 3 skills and all Secondary Students (Form 4 to 7) should possess Level 4 skills, as specified in the framework) in Information Literacy Framework for Hong Kong Students (2005), it is believed that continued and sustained practice and training, serves as an excellent foundation to augment information literacy in students.

Based upon information literacy standards, there are four dimensions: cognitive dimension, meta-cognitive dimension, affective dimension, and socio-cultural dimension. The indicators and learning outcomes in the cognitive dimension are relatively easy to estimate and teach for teachers who are teaching large classes. Both librarians and teachers must continually work to help students to develop information literacy skills. However, the indicators under the remaining three dimensions are not easy to measure in the implementation process, merely through library lessons and the curriculum.

\subsection{Students'Needs}

As Hong Kong continues to develop and make its education policy progressive, the Education Bureau is looking at fine-tuning the Medium of Instruction (MOI), with the intention of implementing English at the Secondary 1 level starting from the 2010/11 school year, and it will then continue to implement English as the MOI each year, up to a higher form at junior secondary levels. MOI fine-tuning promotes bi-lingual instruction in secondary schools, which aim to differentiate themselves from Chinese language secondary schools.

In order to work towards a smooth transition for students from primary to secondary school, the school administrator has decided to conduct additional workshops for Form 1 and Form 2 grades. In these workshops, the teacher is expected to provide supporting materials, inclusive of updated books, news, videos, and cross-disciplinary references to help out students. Taking 
into consideration the potential needs and requirements of students, the school library organizes lessons and orientation modules for students when they graduate to the Form 1 level.

As students graduate to higher grades, evaluating factors and considerations change, primarily because older students inevitably have different needs. Since students in primary grades are yet in the process of developing their knowledge, with reference to their self-learning abilities and enhancing their interests to gain mastery over their skills, their teachers will organize varied knowledge-building activities and relevant learning practices for them. Whereas, senior students need to master these learning skills proficiently, in order to be eligible for the Diploma of Secondary Education (DSE) Examination, and hence they will have a completely different set of learning activities at school.

\subsection{Comments and Suggestions}

It is evident from the results and discussion that the collaboration between librarians and teachers at the school leaves much to be desired. Several reasons can be cited for the discrepancy in their relationship:

- They possess insufficient and inadequate awareness of information literacy instruction, and the roles they are expected to play in imparting that knowledge.

- $\quad$ The librarians in the school appear to play a passive role and do not render satisfactory help to facilitate teachers in analyzing and evaluating students' needs.

- The school very obviously has developed no clear and concise guidelines to implement information literacy instruction across the school.

Based on the above, the school should formulate methods aimed at improving its librarians' and teachers' understanding of the information literacy program. The staff should endeavor to learn about their strengths and responsibilities in the field of information literacy instruction, which in the long run would serve to hugely benefit the students. They could work together to design the worksheets for the mapping, teaching, and evaluation processes. Furthermore, the staff, especially the librarians could be directed towards competently and efficiently utilizing the resources that are available to them and thus, they could augment the services they provide to the rest of the school.

\section{Conclusion}

The ability to access, evaluate and use information from a variety of sources is central to successful learning, and the concept of information literacy has therefore assumed a dominant role in current academics. This study explored the collaboration between librarians and teachers for teaching the curriculum at a secondary school in Hong Kong. The ultimate goal is to integrate the teachers' and librarian's distinctive areas of expertise across the curriculum, so that information literacy will play a central role in the curriculum programs of the future.

In this study, the research methodology utilized a qualitative approach. For the purpose of data collection, interviews were conducted with a Librarian Director and three English 
subject teachers, to explore the current status of information literacy instruction in the school on how collaboration occurs between librarians and teachers, whilst imparting the curriculum. The process of collaboration is described in the discussion section of the study. The study revealed that the alliance between librarians and teachers on development of information literacy instruction for secondary students in the school leaves much to be desired.

Teachers and librarians must work closely with students to design, implement, and revise their skills, to enable them to master the requisite information processing skills and understanding; to develop students as thoughtful and introspective learners; to enable students to acknowledge the value of independent and community-based learning; and, ultimately, to empower students with better self-sufficiency and social responsibility concerning the use of information.

\section{References}

American Association of School Librarians, \& Association for Educational Communications and Technology. (1998). Information power: Buiding information literacy partnerships for learning. Chicago; London: American Library Association.

American Library Association. (1989). Presidential Committee on Information Literacy: Final Report. Retrieved from http://www.ala.org/acrl/publications/whitepapers/presidential

Anday, V. G. (2006). The Role of Libraries and Librarians in Information Literacy. Retrieved from http://www.slideshare.net/plaistrlc/the-role-of-libraries-and-librarians-in-information-literacy Apple Corp. (2001). Curriculum mapping. In S. Hughes-Hassell \& A. Wheelock (Eds.), The information-powered school. Chicago: American Library Association.

Association of College and Research Libraries. (2000). Information Literacy Competency Standards for Higher Education. Retrieved from http://www.ala.org/acrl/standards/informationliteracycompetency

Behrens, S. J. (1994). A conceptual analysis and historical overview of information literacy. College and Research Libraries, 55(4), 309-322.

Burchinal, L. G. (1976). The communications revolution: America's third century challenge College Station, TX: A\&M University Library.

Compaine, B. M. (1984). Information Technology And Cultural Change: Toward A New Literacy?, Cambridge, Massachusetts: Harvard University and Center for Information Policy Research.

Cox, C. N., \& Lindsay, E. B. (2008). Information literacy instruction handbook. Chicago: Association of College and Research Libraries.

Denscombe, M. (2007). The Good Research Guide for small-scale social research projects (3rd Ed ed.), Open University Press.

Eisenberg, B. M. (2008). Information literacy: Essential Skills for the Information Age. Journal of Library \& Information Technology, 2, 39-47. 
Eisenberg, B. M., \& Berkowitz, B. (1990). Information problem solving: The Big Six skills approach to library and information skills instruction. Norwood, NJ: Ablex Publishing Corporation

Fister, B. (2008). Chasing our long tails. ACRLog. Retrieved from http://acrlog.org/2008/07/18/chasing-our-long-tails/

Garfield, E. (1979). 2001: An information society?. Journal of Information Science, 1, 209-215.

Horton, F. W., Jr. (1983). Information Literacy vs. Computer Literacy. Bulletin of the American Society for Information Science, 9(4), 14-16. http://dx.doi.org/10.1177/016555157900100404

Education and Manpower Bureau. (2005). Information Literacy Framework for Hong Kong Students. Retrieved from http://www.edb.gov.hk/attachment/en/edu-system/primary-secondary/applicable-to-primary-s econdary/it-in-edu/il_eng.pdf

Jacobs, H. H. (1997). Mapping the Big Picture: Integrating Curriculum and Assessment K-12. Alexandria: Association for Supervision and Curriculum Development.

Jenlin, C. (2003). The Relationships Between Junior High School Teachers' Information Integration of Informationation Technology Into Curriculum in Taiwan Spalding University. Spalding University.

Johnston, B., \& Webber, S. (2003). Information Literacy in Higher Education: A review and case study. Studies in Higher Education, 28(3), 335-352. http://dx.doi.org/10.1080/03075070309295

Kuhlthau, C. C. (1987). Information skills for an information society: a review of research. Syracuse. NY: ERIC Clearinghouse on Information Resources.

Kuhlthau, C. C. (1993). A principle of uncertainty for information seeking. Journal of Documentation, 49(4), 339-355. http://dx.doi.org/10.1108/eb026918

Manchester Metropolitan University (2007). Information Literacy Literature Review. Retrieved from http://www.learnhigher.mmu.ac.uk/research/InfoLit-Literature-Review.pdf

Montiel-Overall (2008). Teacher and librarian collaboration: A qualitative study. Library \& Information Science Research, 30(2), 145-155. http://dx.doi.org/10.1016/j.lisr.2007.06.008

Siemens, G. (2002). Lessons Learned Teaching Online. Retrieved from http://www.elearnspace.org/Articles/lessonslearnedteaching.htm.

Spitzer, K. L., Eisenberg, M. B., Lowe, C. A., \& Doyle, C. S. (1998). Information literacy: Essential skills for the information age. Syracuse, N.Y: ERIC Clearinghouse on Information \& Technology, Syracuse University.

Curriculum Development Council. (1999). Syllabuses for secondary schools: English Language secondary 1-5. Hong Kong: Education Department. 